\title{
Isoimmune neonatal thrombocytopenic purpura
}

\author{
P GALEA, M J PATRICK, AND K M GOEL
}

Royal Hospital for Sick Children, Glasgow

SUMMARY Ten cases of isoimmune neonatal thrombocytopenic purpura (4 pairs of siblings and 2 singletons) are described. The condition was diagnosed by excluding other causes of thrombocytopenia, and in 8 cases it was confirmed by detecting antiplatelet antibodies in the mother. Perhaps steroids should be given to affected infants as soon as the condition is diagnosed in order to stabilise the capillary membrane. Exchange transfusion, using platelet antigen-negative blood if available, helps to remove antibodies and should be followed by the infusion of antigen-negative platelets, easily obtained from the mother by platelet-phoresis. The use of random donor platelets (as in 3 of these cases) was ineffective because $98 \%$ of the population are platelet antigen-positive. Nine of the infants recovered completely. The exception was an infant who developed hydrocephalus, possibly as a result of intracranial haemorrhage.

Isoimmune neonatal thrombocytopenic purpura (INTP) is rare; $98 \%$ of the population are platelet antigen-( $\mathrm{Pl}^{\mathrm{A} 1}$ or $\left.\mathrm{ZW}{ }^{\mathrm{A}}\right)$ positive, the characteristic being autosomal dominant in inheritance. Only the remaining $2 \%$ of the female population are thus capable of sensitisation. Manifestations of maternal incompatibility, with sensitisation of the $\mathrm{Pl}^{\mathrm{A} 1}$ negative mother and thrombocytopenia in the $\mathrm{PI}^{\mathrm{A} 1}$ positive infant, occur once or twice in 10000 births. $^{1-2}$ Several platelet antigens have been implicated in INTP. Some are restricted to platelets, others are shared by leucocytes and may be identical with certain antigens of the HLA system. The platelet antigenic system most commonly associated with INTP has been designated $\mathrm{PI}^{\mathrm{A} 1}$ or $\mathrm{ZW}^{\mathrm{A}}$. Therefore the finding of reactivity for the $\mathrm{Pl}^{\mathrm{Al}}$ antigen in the mother of an infant with neonatal thrombocytopenia is strong presumptive evidence of isoimmunisation to this antigen. ${ }^{3}$

The first affected $\mathrm{Pl}^{\mathrm{A}}{ }^{1}$-positive infant of a $\mathrm{Pl}^{\mathrm{A}} \mathbf{1}_{\text {- }}$ negative mother is generally born undiagnosed until thrombocytopenia is manifest by haemorrhage. Fatalities, often due to intracranial haemorrhage, have occurred in about $14 \%$ of reported cases. ${ }^{4}$

The diagnosis of INTP is based on the exclusion of other causes of neonatal thrombocytopenia, the demonstration of antiplatelet antibodies in the maternal serum, and the response to the infusion of $\mathrm{Pl}^{\mathrm{A} 1}$-negative platelets. The clinical history of $\mathbf{1 0}$ infants with INTP, with special reference to treatment is described.

\section{Clinical material}

Ten infants (4 pairs of siblings and 2 singletons) were admitted to special care nurseries in Glasgow between October 1971 and October 1978, showing the prevalence of the disorder in Glasgow. None of these babies was referred from hospitals outside Glasgow. There were 7 boys and 3 girls. Details of the clinical and laboratory findings are given in Tables 1 and 2. Maternal platelet counts were normal and there was no history of drug ingestion during pregnancy. There was no clinical or laboratory evidence of bacterial or viral infection.

The platelet antibodies were detected using a simple immunofluorescence test developed at the Central Laboratory of the Netherlands Red Cross Blood Transfusion Service in Amsterdam. ${ }^{5}$

\section{Discussion}

INTP should be suspected in any purpuric, but otherwise healthy, infant of a mother whose platelet count is normal. The diagnosis can be confirmed by the demonstration in the maternal serum of antibody which reacts with the platelets of the infant or the father, but not with those of the mother. Laboratory confirmation of isoimmunisation is difficult. The maternal antibody in these cases is of the complement-fixing or blocking variety and generally is not detectable by usual tests for platelet agglutinins. Nevertheless by using paraformalde- 
Table 1 Clinical findings in 10 cases of isoimmune neonatal thrombocytopenic purpura

\begin{tabular}{|c|c|c|c|c|c|c|}
\hline Case & Sex & $\begin{array}{l}\text { Birthweight } \\
(k g)\end{array}$ & $\begin{array}{l}\text { Gestation } \\
\text { (weeks) }\end{array}$ & $\begin{array}{l}\text { Mode of } \\
\text { delivery }\end{array}$ & Apgar score & Clinical features \\
\hline 1 & $\mathbf{M}$ & $3 \cdot 60$ & 41 & Forceps & 6 at $1 \mathrm{~min}$ & $\begin{array}{l}\text { Day } 1 \text {, petechiae on trunk, } \\
\text { bruising on forehead } \\
\text { Day } 2,3,4 \text {, irritable baby } \\
\text { Day } 11 \text {, haematuria and melaena } \\
\text { Week } 4 \text {, rapidly increasing head cir- } \\
\text { cumference } \\
\text { Week } 5 \text {, hydrocephalus confirmed by air } \\
\text { ventriculography }\end{array}$ \\
\hline 2 (sister of Case 1$)$ & $\mathbf{F}$ & $3 \cdot 53$ & 40 & Spontaneous & 9 at $1 \mathrm{~min}$ & Day 1, petechiae on trunk and limbs \\
\hline 3 & $\mathbf{M}$ & 3.01 & 40 & Spontaneous & 9 at $1 \mathrm{~min}$ & $\begin{array}{l}\text { Day 1, bruising and petechiae on trunk and } \\
\text { limbs particularly in groin and axillae }\end{array}$ \\
\hline 4 (brother of Case 3 ) & $\mathbf{M}$ & $3 \cdot 28$ & 41 & Spontaneous & 8 at $1 \mathrm{~min}$ & $\begin{array}{l}\text { Day } 1 \text {, petechiae on trunk rapidly extending } \\
\text { to limbs }\end{array}$ \\
\hline 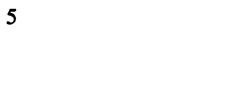 & $\mathbf{M}$ & $2 \cdot 60$ & 38 & Spontaneous & 8 at $1 \mathrm{~min}$ & $\begin{array}{l}\text { Day } 1 \text {, generalised petechiae on arms and } \\
\text { trunk, mild jaundice } \\
\text { Day } 4 \text {, maximum serum bilirubin } 360 \\
\mu \mathrm{mol} / \mathrm{l}(21 \mathrm{mg} / 100 \mathrm{ml})\end{array}$ \\
\hline 6 (brother of Case 5) & $\mathbf{M}$ & $3 \cdot 30$ & 40 & Spontaneous & 9 at $1 \mathrm{~min}$ & $\begin{array}{l}\text { Day } 1 \text {, facial petechiae rapidly extending } \\
\text { to trunk and limbs. Blood in vomitus and } \\
\text { urine } \\
\text { Day } 2 \text {, jaundiced, serum bilirubin } 245 \\
\mu \mathrm{mol} / 1(14 \mathrm{mg} / 100 \mathrm{ml}) \text {. Irritable }\end{array}$ \\
\hline $\begin{array}{l}7 \\
8 \text { (sister of Case 7) }\end{array}$ & $\begin{array}{l}\mathbf{M} \\
\mathbf{F}\end{array}$ & $\begin{array}{l}3 \cdot 78 \\
3 \cdot 81\end{array}$ & $\begin{array}{l}40 \\
40\end{array}$ & $\begin{array}{l}\text { Spontaneous } \\
\text { Spontaneous }\end{array}$ & $\begin{array}{l}10 \text { at } 1 \mathrm{~min} \\
10 \text { at } 2 \mathrm{~min}\end{array}$ & $\begin{array}{l}\text { Day } 1 \text {, generalised petechiae and bruising } \\
\text { Birth, extensive scalp bruising } \\
\text { Day 1, fresh blood in gastric aspirate. } \\
\text { Fine petechiae on trunk }\end{array}$ \\
\hline 9 & $\mathbf{M}$ & $3 \cdot 56$ & 40 & Spontaneous & 10 at $2 \mathrm{~min}$ & $\begin{array}{l}\text { Birth, petechiae on face } \\
\text { Day } 1 \text {, petechiae on trunk and limbs }\end{array}$ \\
\hline 10 & $\mathrm{~F}$ & 1.45 & 35 & Spontaneous & 9 at $1 \mathrm{~min}$ & $\begin{array}{l}\text { Birth, subconjuctival haemorrhage } \\
\text { Day } 1 \text {, bruising on back, } \\
\text { petechiae on trunk }\end{array}$ \\
\hline
\end{tabular}

Table 2 Management of 10 cases of isoimmune neonatal thrombocytopenic purpura

\begin{tabular}{|c|c|c|c|c|c|}
\hline Case & $\begin{array}{l}\text { First platelet } \\
\text { count }\left(\times 10^{9} / l\right)\end{array}$ & $\begin{array}{l}\text { First normal } \\
\text { platelet count }\end{array}$ & $\begin{array}{l}\text { Maternal } \\
\text { antibody }\end{array}$ & Treatment & Final outcome \\
\hline 1 & 29 & Week 4 & Not done & $\begin{array}{l}\text { Prednisolone } 10 \mathrm{mg} \text { a day for } 6 \text { weeks. } \\
\text { Random donor platelet infusion } \times 6\end{array}$ & $\begin{array}{r}\text { Hydrocephalus with } \\
\text { Spitz-Holter valve }\end{array}$ \\
\hline 2 & 15 & Day 6 & Not done & $\begin{array}{l}\text { Prednisolone } 15 \mathrm{mg} \text { a day for } 10 \text { days. } \\
\text { Maternal platelet infusion } \times 2\end{array}$ & Recovered \\
\hline 3 & 25 & Week 5 & $\begin{array}{l}\text { Present (new } \\
\text { undiagnosed } \\
\text { specificity) }\end{array}$ & $\begin{array}{l}\text { Prednisolone } 15 \mathrm{mg} \text { a day for } 6 \text { weeks. } \\
\text { Exchange transfusion. } \\
\text { Random donor platelet infusion. }\end{array}$ & Recovered \\
\hline 4 & 10 & Day 17 & Present & $\begin{array}{l}\text { Exchange transfusion. } \\
\text { Random donor platelet infusion } \times 1 \text {. } \\
\text { Maternal platelet infusion } \times 1\end{array}$ & Recovered \\
\hline 5 & $\begin{array}{r}126 \\
20\end{array}$ & Week 2 & Present anti $\mathbf{Z w}^{\mathbf{A}}$ & $\mathrm{Nil}$ & Recovered \\
\hline 6 & 69 & Day 4 & Present & Prednisolone $20 \mathrm{mg}$ a day for 10 days & Recovered \\
\hline 7 & 10 & Week 4 & Present HLA $\mathbf{A}_{1}+\mathbf{A}_{3}$ & Nil & Recovered \\
\hline 8 & 44 & Week 4 & Present & Prednisolone $10 \mathrm{mg}$ a day for 3 weeks & Recovered \\
\hline 9 & 3 & Day 5 & $\begin{array}{l}\text { Present } \\
\quad \text { anti } Z_{W^{A}}\end{array}$ & Nil & Recovered \\
\hline 10 & 24 & Day 7 & Anti ZwA & Random donor platelets $\times 1$ & Recovered \\
\hline
\end{tabular}

hyde-fixed platelets, a simple method for detecting platelet antibodies, the platelet suspension immunofluorescence test has recently been developed. ${ }^{5} \mathrm{~A}$ petechial rash, with or without bruising, is evident within minutes or a few hours of delivery. The platelet count is usually low by the time the bleeding manifestations occur, as in 9 of our 10 infants. The presence of an initially normal platelet count, as in Case 5, does not exclude INTP. It may be that in a few cases the platelets are inactivated by the antibodies but remain in circulation for some time before being removed.

A logical way of treating an infant with INTP would be to remove as much platelet antibody as 


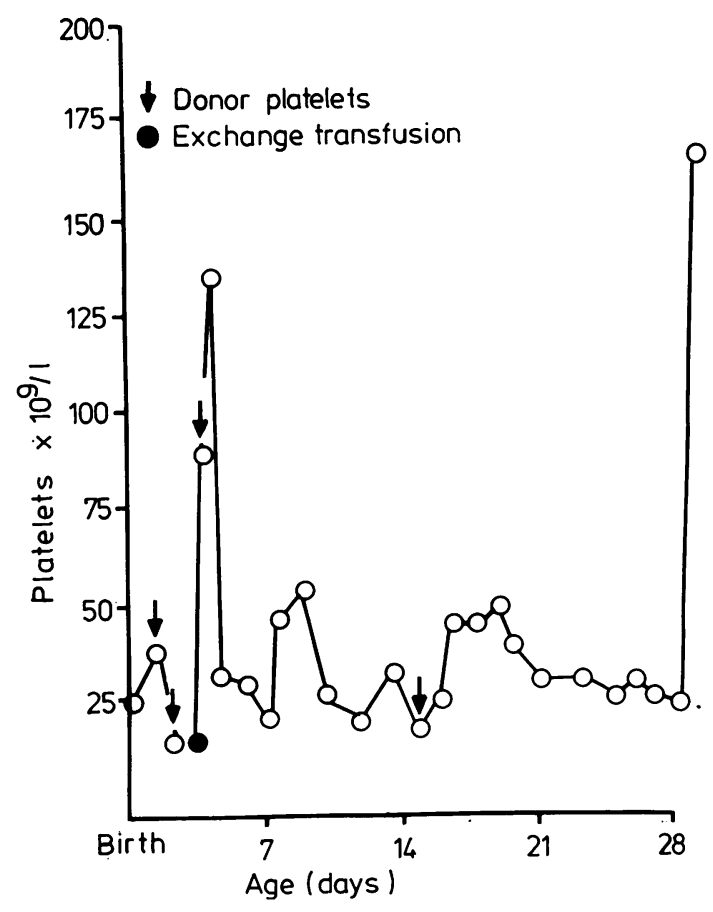

Fig. 1 (Case 3.) Serial platelet counts showing rapid sequestration of random donor platelets even after exchange transfusion.

possible by exchange transfusion, and then to replenish the infant's platelets with a transfusion of $\mathrm{PI}^{\mathrm{A} 1}$-negative platelets. As in Cases 3 and 4, random donor platelets were rapidly sequestrated when infused, even after exchange transfusion, suggesting that a significant quantity of antibody remained and that the random donor platelets were $\mathbf{P I}^{\mathbf{A}}$-positive (Fig. 1). There is a $98 \%$ risk of random donor platelets being $\mathrm{PlAl}^{\mathrm{Al}}$-positive and, as in Cases 1, 3, 4, and 10, the infused platelets were removed within a few hours. This has also been the experience of other workers. ${ }^{6}$ The most readily available source of $\mathrm{PI}^{\mathrm{Al}}$-negative platelets is the mother herself. Cases 2 and 4 clearly indicate the efficacy of using platelets from the mother (Fig. 2).

The action of prednisolone in this condition is difficult to assess and it is unlikely that it reduces the duration of the thrombocytopenia. The capillary membrane-stabilising action of steroids may help to reduce the risk of haemorrhage. In Cases 1, 2, 3, and 8, steroids had no effect on the platelet counts. Although in Case 6 the platelet count rose sharply within 36 hours of starting prednisolone, if the antibody titre is not excessively high, the platelet count

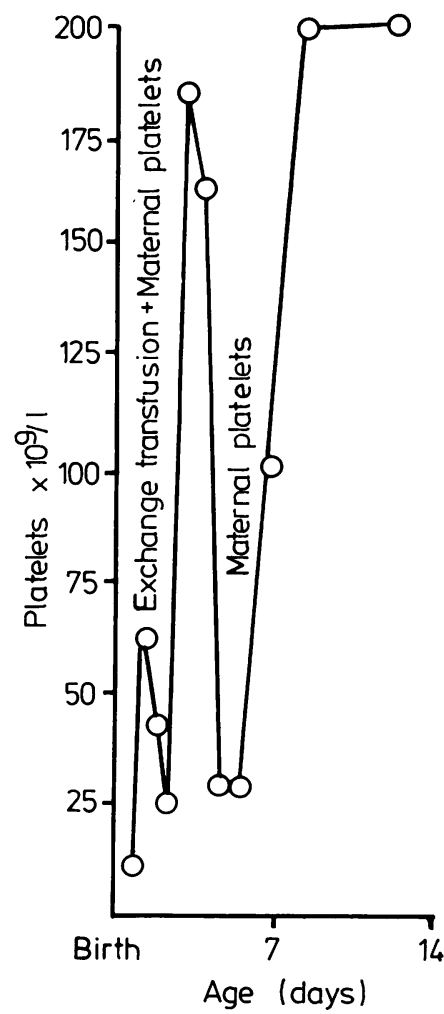

Fig. 2 (Case 2.) Serial platelet counts showing the efficacy of using maternal platelets.

could spontaneously rise to normal levels within a few days, as in Cases 5, 7, and 9.

Generally INTP follows a mild course and there is complete recovery between one and five weeks later without any sequelae. The period of greatest danger from haemorrhage is during the first 24 hours of life and is probably related to birth trauma and asphyxia. In our series all infants, except the one delivered by forceps (Case 1), recovered without sequelae.

When a pregnant mother of previously affected children is about to be delivered, one has to consider the safest way of delivering the baby with the least trauma. If an easy spontaneous delivery is not possible, the dangers of an instrumental or breech delivery have to be weighed against the relative safety of caesarean section.

In conclusion, the management of an affected infant should ideally start before birth, although it is not possible to diagnose the condition in a primigravida prenatally in the absence of an easy screening test. The administration of antepartum steroids to the mother has been suggested. ${ }^{7}$ This is not without risks and remains to be assessed. Steroids should 
perhaps be given to all affected infants as soon as the condition is confirmed. Exchange transfusion, using PIA1-negative blood if available, may help to remove antibody and lessen the severity of the condition. However the best way of treating a severely affected infant is by the administration of antigen-negative platelets, easily obtained from the mother by platelet-phoresis.

We thank Professor F Cockburn and Dr R A Shanks for constructive criticism and guidance in the preparation of this paper.

\section{References}

1 Shulman N R, Marder V J, Hiller M C, Collier E M. Platelet and leucocyte isoantigens and their antibodies: serologic, physiologic and clinical studies. Prog Hematol 1964; 4: 222-304.

2 McIntosh M D, O'Brien R T, Schwartz A D, Pearson H A. Neonatal isoimmune purpura: response to platelet infusion. J Pediatr 1973; 82: 1020-7.
3 Pearson H A, McIntosh S. Neonatal thrombocytopenia. Clin Haematol 1978; 7: 111-22.

4 Oski F A, Naiman J L. Hematologic problems in the newborn, second edition. Philadelphia: Saunders, 1972: 291.

5 von dem Borne A E G Kr, Verheugt F W A, Oosterhof F, von Riesz E, Brutel de la Rivière A, Engelfriet C P. A simple immunofluorescence test for the detection of platelet antibodies. Br J Haematol 1978; 39: 195-207.

6 Adner M M, Fisch G P, Starobin S G, Aster R H. Use of 'compatible' platelet transfusions in treatment of congenital isoimmune thrombocytopenic purpura. $N$ Engl J Med 1969; 280: 244-7.

7 Pearson H A, Shulman N R, Marder V J, Cone T E, Jr. Isoimmune neonatal thrombocytopenic purpura - clinical and therapeutic considerations. Blood 1964; 23: 154-77.

Correspondence to Dr K M Goel, Royal Hospital for Sick Children, Yorkhill, Glasgow G3 8SJ.

Received 21 November-1979 